\title{
Techno-economic demand projections and scenarios for the Bolivian energy system
}

\author{
Peña Balderrama $\mathrm{JG}^{\mathrm{a}}$, Broad $\mathrm{O}^{\mathrm{a}}$, Sevillano $\mathrm{RC}^{\mathrm{c}}$, Alejo L ${ }^{\mathrm{b}}$, Howells $\mathrm{M}^{\mathrm{a}}$ \\ ${ }^{a}$ KTH Royal Institute of Technology, Department of Energy Technology, Division of Energy \\ Systems Analysis, Brinellvagen 68, 10044 Stockholm, Sweden \\ ${ }^{\mathrm{b}}$ Universidad Mayor de San Simon (UMSS), Facultad de Ciencias y Tecnología, Centro de \\ Tecnología Agroindustrial, Cochabamba, Bolivia \\ ${ }^{\mathrm{c}}$ Unidad de Analisis de Políticas Sociales y Economicas (UDAPE), Ministerio de Planificacion del \\ Desarrollo, La Paz, Bolivia.
}

\section{Introduction}

Although energy itself does not ensure human well-being, having access to energy has been identified as essential to fulfilling many social, economic and environment needs of the Sustainable Development Goals, (SDGs) [1][2]. In developing economies, as standards of living rise with economic development, the energy consumption patterns tends to increase, encouraging the intensification of energy use for industrial and productive activities [3]. Nevertheless, most of the dominating energy consumption and supply patterns are clearly unsustainable when related to growing resource depletion and environmental degradation.

Recent studies such as the Global Energy Assessment (GEA) pathways demonstrate the technical feasibility of achieving sustainability for such objectives as improved energy access, affordable energy services, better air quality and higher energy security simultaneously through integrated policy design [4].

Achieving sustainability objectives offer multiple benefits beyond environmental and monetary value. Studies have demonstrated the relation between energy and social development showing that energy access allows better conditions for education, increased quality of life, health benefits and higher income opportunities [5][6]

Meeting sustainability conditions during the economic development process implies cost-effective investments, the tightening of climate legislation and the introduction of new energy policies [7]. These should aim wide, targeting from the very basic energy requirements for achieving social equity, to cutting edge challenges of greater efficiency in energy production and rational use of natural energy resourcesby "win-win" solutions [8].

In this context, energy forecasts have been widely used as a point of departure for the articulation of political goals relating to energy development [9]. The forecast outputs represent key data for investment planning research, climate change and natural resource management [10]. Energy forecasting models for policy formulation use different exogenous variables such as population, income, growth factors and technology to determine energy consumption patterns [11][12] with a scenario formulation that provides insights into specific policies and measures.

Although energy models do not determine policy or substitute political judgement, they project the long term consequences of policy targets, representing a tool to develop informed choices required to tackle the sustainable development challenges.

\section{Energy and development process in Bolivia}

Bolivia is a land-locked country in South America and is classified as a lower middle income economy [13] with a multi-ethnic population of 10.67 million. It has a diverse geography, including Andean mountains, deserts, valleys and tropical forests[14]. The country has considerable wealth in minerals and energy resources and has the $2^{\text {nd }}$ largest reserves of Natural Gas in South America which are fast becoming a strategic source of its economic prospects [15]. 
From an access perspective however, about 700 thousand Bolivian households were still without access to electricity in 2012 [16] and about 750 thousand households still cooked with traditional forms of biomass [17]. Like most of developing countries, access to modern energy services is characterized by in-equitable access between the rural poor and the urban areas.

Since 2006, Bolivia has undergone an institutional change with increased participation of the government in decisions relating to the economy and energy sectors [18]. The Energy Development Plan 2008-2027 [16] outlines the objectives of national energy policies such as energy security, efficiency and sovereignty; it also identifies strategic targets with a special focus on increasing the standard of living of the poor population and diversifying the electricity generation mix through identified renewable technologies.

In addition, the new Bolivian State Constitution approved by referendum in 2009 [18] in the paragraph I of Article 378, defines the Bolivia's natural resources as a strategic industrial strength. For this purpose, in 2015 several energy intensive projects were identified in the investment portfolio, $\mathrm{PDES}^{1}$, to be implemented by 2025 [19]. However, Bolivia still lacks of energy efficient standards in products and emissions cap regulations.

Few energy-related forecasts for Bolivia have been developed and most are focused on isolated sectors offering only a partial overview of future energy demand trends. These studies, available in the literature, include such reports as the assessment of future demands for natural gas within committed industrial and electric projects [20], the emissions inventory for Bolivia [21], as well as city-level studies such emissions inventory for the city of Cochabamba [22] or ministerial reports such as hydrocarbons [23] and electricity demand forecasts [24][25] and energy scenarios 2008-2027 [16].

The scope of this research is to explore and inform future energy requirements for Bolivia using a pragmatic methodology. The model, developed using LEAP ${ }^{2}$ [26], represents the first National level Energy forecast for Bolivia that combines trends in demography, economy, technology and policy with a structure combining bottom-up, top-down and econometric methodologies. The results offer insights to explore and compare, in a scenario space future energy alternatives while, representing key data looking at forthcoming policy and investments in the supply side.

The structure of the paper proceeds as follows: Section 2 introduces some key considerations relating the modelling approach. Section 3 describes the model structure, scenarios and key assumptions with which the projections were prepared. Different paragraphs are used to describe the methodology used to model each sector and subsector. Section 4 presents the model results in 3 sub-sections: the first shows the Reference energy scenario results, the second presents a parameter sensitivity analysis of the energy model under three macroeconomic scenarios and the third sub-section compares the results of the Reference energy scenario with three alternative energy scenarios to investigate the impact of various policies and measures. Section 6 discusses the strengths and limitations of the methods used. Finally, Section 7 concludes with the key findings of the model and scenarios.

\section{Modelling Approach}

\section{Energy models and Indicators}

Energy systems models are developed to support sustainable planning (policy and strategy) in a large selection of countries[9] with a planning horizon ranging from short-term -1 day to 1 year- to long term -5 years ahead. They have been defined as a comprehensive methodology for the analysis of complex problems such as the interaction between energy and economy, fuel or technology substitution using formal mathematical techniques [27]. To develop demand projections, energy models determine energy consumption patterns affected by several factors such as economics, industrial development, consumer behaviour and climate.

Diverse and complex energy demand forecasting methodologies have been developed to study and project the energy demand patterns. The literature is rich in forecasting methods, Sughanti et al, classified them in 11 broad

\footnotetext{
${ }^{1}$ Economic and Social Development Plan (PDES in Spanish acronym)

${ }^{2}$ Long-range Energy Alternative Planning software
} 
categories with 364 applied energy examples, ranging from classic model formulations including accounting, top-down, bottom-up (end-use) and econometric approaches, to soft computing techniques widely used in energy demand forecasting such as artificial/expert systems, genetic algorithms, particle swarm optimization and other hybrid models [28].

Notwithstanding the diversity of energy models available, the energy consumption in developing economies is growing fast and randomly. The later is due to the relative inequality in growth that affects different sectors of the economy. Thus, a single mathematical method cannot be generalised to perform well enough when modelling the entire energy demand.

To forecast the long-term energy requirements, specific bottom-up and top-down methodologies were applied to each sector. These methods are not mutually exclusive and can also be combined in a hybrid model [29] in which both methodologies interact with each other [30][31].

Bottom-up models are data intensive, total energy consumption is obtained through aggregating various energyusing technologies defined by technical characteristics such as efficiency and life cycle[32], while top-down models analyse the energy systems from a higher/aggregated level with its interaction with the economy. Technologies are aggregates and modelled implicitly through average energy intensities. Both methodologies rely on exogenous parameters such as GDP, population, volume of production to generate a forecast. Since a lack of detail in energy end-use data restricts the use of a complete bottom-up demand model, for certain sectors of the economy, this work combines such approaches with top-down analyses which are soft linked with a Computable General Equilibrium (CGE) model.

Energy indicators, commonly named energy intensities when related to a monetary base, provide a deep understanding of linkages within the energy-economy nexus [33]. Monitoring energy indicators therefore helps to assess current and future effects of energy use and to measure progress on sustainable development goals [34]. They also help to lead policymakers towards taking better decisions and more effective actions by presenting simplified, clear and aggregated information.

Bolivia is in the early stages of monitoring energy indicators. Since 2011 it has been participating along with 19 other Latin American countries in the $\mathrm{BIEE}^{3}$ program from ECLAC ${ }^{4}$, consolidating a sectorial monetarybased energy indicator database from 2000-2012. Notwithstanding this database, our top-down modelling projections were based on historical energy intensities for an extended variety of units of consumption including: monetary (GVA), volume of production (Tons), area (hectare) and others (passenger-km, tonne-km).

\section{LEAP}

The Long range Energy Alternatives Planning System (LEAP), is a powerful, versatile software for energy planning and climate change mitigation studies developed by the Stockholm Environment Institute (SEI). It has been adopted by organizations in nearly 190 countries worldwide and is used to model energy consumption, production and resource management in over 200 journal publications [26]. Its versatility for modelling different energy systems supports, in a single model, a wide range of modelling methodologies for both the demand and the supply side, including bottom-up [35], top-down macroeconomic modelling and also hybrid model possibilities [29]. In addition, the modelling framework can be scaled from regional [36], national [37], [38], and city perspectives [39], [40], and can address electricity demand-supply analyses[41], [42], [43], costbenefit studies [44], emission mitigation assessments [45], [46] and other specific sectorial analyses including e.g. transport [47], [48] or landfill gas [49] in developed and developing countries.

The potential role of LEAP in Bolivia as a tool for energy planning has been acknowledged by the Ministry of Hydrocarbons and Energy (MHE) since 2012 when a macro-economic model was developed to explore energy scenarios [16][50]. The long term vision of the MHE is to use LEAP as a planning tool and to improve and update in a yearly basis the current macro-economic energy model with further end-use information.to be able to evaluate the progress on specific measures such technological replacement or fuel substitution.

\footnotetext{
${ }^{3}$ Base for Energy Efficiency Indicators

${ }^{4}$ Economic Commission for Latin America and the Caribbean
} 


\section{Methodology}

\subsection{Model Structure}

The energy demand model uses a tree structure to delineate different consumers and their sub-sectors. While each sector and sub-sector are modelled independently and do not interact, a combination of methodologies was used to model each branch depending on data availability (Table 1). The tree structure of the energy demand system is described in $\boldsymbol{F i g} \mathbf{1}$ using a radial tree assembly.

Table 1 Methodology approach by sector and subsector

\begin{tabular}{|c|c|c|c|}
\hline Sector & Sub-sector & $\begin{array}{l}\text { Methodology } \\
\text { Approach }\end{array}$ & $\begin{array}{l}\text { Unit of } \\
\text { consumption }\end{array}$ \\
\hline Residential & All & Bottom-up & Households \\
\hline Industrial & $\begin{array}{l}\text { Manufacture } \\
\text { Petrochemical } \\
\text { Cement }\end{array}$ & Top-down & $\begin{array}{l}\mathrm{GVA}_{\text {manufacture }} \\
\text { Tonne of production }\end{array}$ \\
\hline $\begin{array}{l}\text { Mining and } \\
\text { Quarrying }\end{array}$ & All & Top-down & Tonne of production \\
\hline Agricultural & All & Bottom-up & Cultivated area \\
\hline Commercial & All & Top-down & GVA $_{\text {commercial }}$ \\
\hline Transport & Private & Bottom-up & Vehicles \\
\hline & $\begin{array}{l}\text { Freight, } \\
\text { Aviation } \\
\text { Rail }\end{array}$ & Top-down & $\begin{array}{l}\text { Tonne-km freight } \\
\text { Passenger-km } \\
\text { aviation } \\
\text { Passenger-km } \\
\text { Tonne-km } \\
\text { rail }\end{array}$ \\
\hline
\end{tabular}

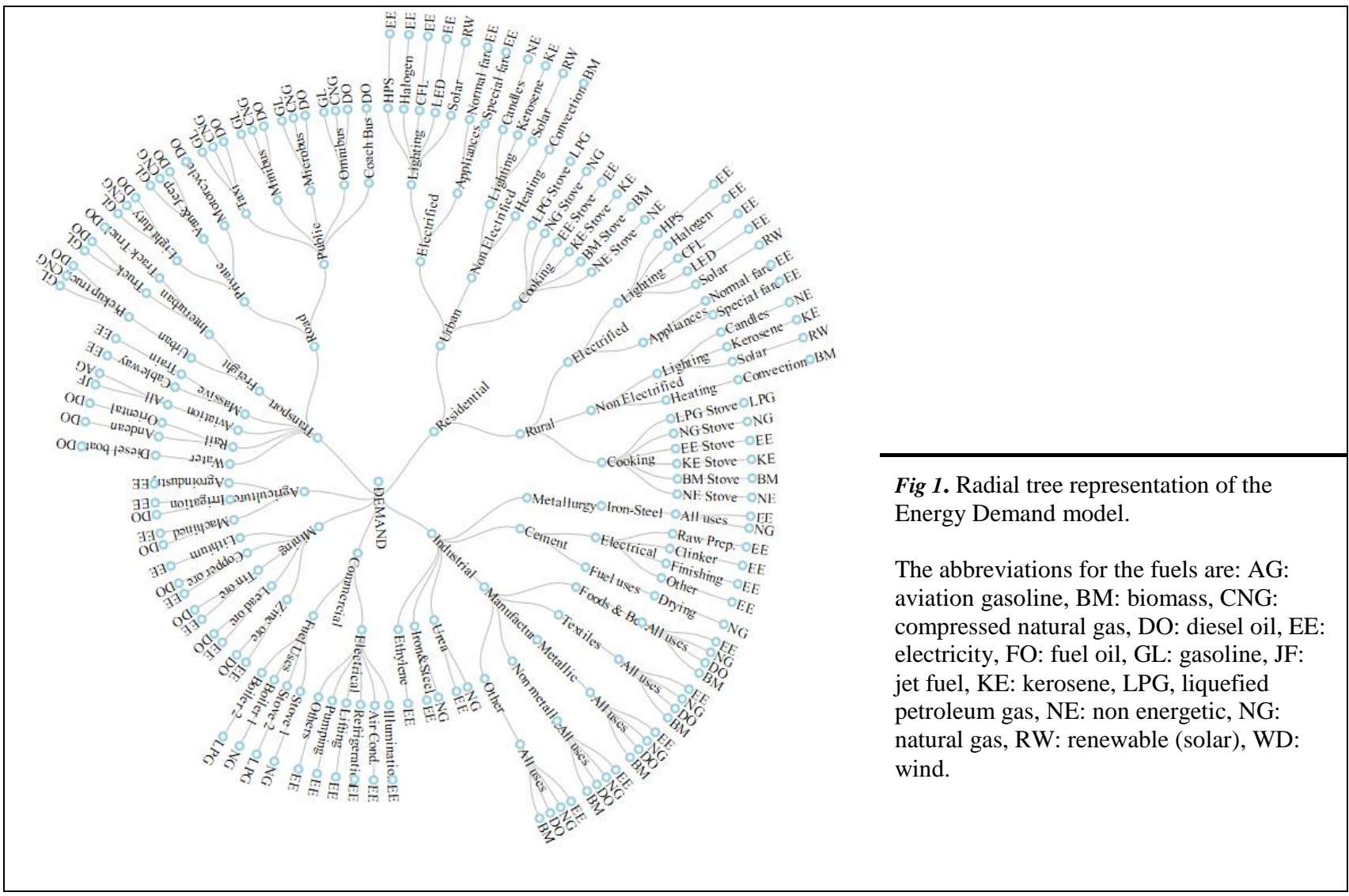

\subsection{Key Assumptions}




\section{Macro-Economic projections}

Projections of Gross Domestic Product, GDP, and Gross Added Value, GVA, were modelled in a Computable General Equilibrium model [51][19][52] and used in the calculations described in the next section.. For all energy scenarios, a single macroeconomic scenario which considers historical trends on public investment was used. Two additional macroeconomic scenarios were modelled to project the GDP and GVA under optimistic and pessimistic assumptions. These projections were used for a sensitivity analysis of the energy model in Section 4.

\section{Scenario Assumptions}

The Reference scenario, REF, presents a hypothetical future in which no other policy actions than those promulgated by the end of 2012 are taken in account. It is used as a reference against which the impacts of forthcoming policy targets to 2035 can be benchmarked. The Energy savings scenario, ES, uses a combination of government targets [50][16] and author's considerations to 2035. The Fuel substitution scenario, FS, assumes traditional-fuel replacement according to government targets by 2025 and extended them to 2035 using linear projections [16]. And a combined scenario, COMB, which includes policies and measures from Scenarios 2 and 3 to assess their aggregated effects.

Details of individual policies and measures included in each scenario and within each sector / subsector are shown in Table 2.

Table 2. Policy and descriptions for each sector and sub-sector.

\begin{tabular}{|c|c|c|c|c|c|}
\hline Scenario & Policy & Sector & Sub-sector & Description & Ref \\
\hline \multirow[t]{3}{*}{ Reference } & Efficient Lighting & $\begin{array}{l}\text { Residential } \\
\text { Commercial }\end{array}$ & Lighting & $\begin{array}{l}\text { Replacement of HPS and Halogen luminaries by CFL and LED } \\
\text { technology. (average } 6.2 \text { million per year) }\end{array}$ & * \\
\hline & Fuel Switch & Residential & Cooking & $\begin{array}{l}\text { Domestic pipeline expansion in urban areas and LPG distribution in } \\
\text { rural areas. (1055 thousand of new connections in the period 2012- } \\
2030 \text { ) }\end{array}$ & [23] \\
\hline & & Transport & All & $\begin{array}{l}\text { Retrofit of gasoline and diesel engines to CNG ( } 4.5 \text { million of } \\
\text { retrofits in the timeframe) }\end{array}$ & [53] \\
\hline \multirow[t]{13}{*}{$\begin{array}{l}\text { Energy } \\
\text { Savings }\end{array}$} & Lighting & $\begin{array}{l}\text { Residential } \\
\text { Commercial }\end{array}$ & Lighting & $\begin{array}{l}\text { Complete linear phase out by } 2050 \text { of HPS and Halogen luminaries } \\
\text { replaced by CFL and LED technology. }\end{array}$ & * \\
\hline & Electrical uses & Residential & Appliances & $\begin{array}{l}\text { Retrofit of inefficient electrical appliances. Overall efficiency } \\
\text { increase } 10 \% \text { to } 2035 \text {. }\end{array}$ & * \\
\hline & & Commercial & All & $\begin{array}{l}\text { Electricity savings in electric appliances through maintenance and } \\
\text { well practices. Potential savings of } 23 \% \text { of electricity consumption. }\end{array}$ & [54] \\
\hline & & Industrial & Cement & $\begin{array}{l}\text { Electricity savings in machinery for raw material preparation, } \\
\text { material transportation and clinker production. } 14.9 \% \text { of savings to } \\
2035 \text {. }\end{array}$ & [50] \\
\hline & & & Manufacture & $\begin{array}{l}\text { Electricity savings in appliances trough right maintenance and } \\
\text { retrofit of inefficient technology. }\end{array}$ & $\begin{array}{c}{[55][} \\
56]\end{array}$ \\
\hline & & Mining & All & Electricity savings in electrochemical processes & [50] \\
\hline & & Agriculture & Irrigation & $12.4 \%$ of potential savings in irrigation using centre pivots & [57] \\
\hline & Heat uses & Commercial & All & $\begin{array}{l}\text { Electricity savings in appliances through maintenance and well } \\
\text { practices. Potential savings of } 20 \%\end{array}$ & [54] \\
\hline & & Industrial & Cement & $\begin{array}{l}\text { Improved driers and clinker preparation machinery. } 20 \% \text { of energy } \\
\text { savings through technological enhancement. }\end{array}$ & [3] \\
\hline & & & Manufacture & $\begin{array}{l}\text { Heat savings through right maintenance and retrofit of inefficient } \\
\text { technology. }\end{array}$ & $\begin{array}{c}{[55][} \\
56]\end{array}$ \\
\hline & & Mining & All & Heat savings in furnaces. & [50] \\
\hline & Driving & Transport & All & Energy savings from eco-driving and regular maintenance. & [50] \\
\hline & Modal Shift & Transport & Public & $\begin{array}{l}\text { Passenger-km shift from of minibuses, microbuses and taxis to } \\
\text { coach buses and massive transport alternatives }\end{array}$ & $*$ \\
\hline \multirow[t]{5}{*}{ Fuel Switch } & Fuel Switch & Residential & Cooking & $\begin{array}{l}\text { Domestic pipeline further of } 1855 \text { thousand of new domestic } \\
\text { connections in the period 2012-2035. Electric stoves penetration of } \\
15 \% \text { to } 2035 \text { (only in urban). }\end{array}$ & * \\
\hline & & Commercial & Heat & $\begin{array}{l}\text { Switch to electricity for heat-use purposes } 5 \% \text { stoves and } 15 \% \text { of } \\
\text { boilers by } 2035 \text {. }\end{array}$ & $\begin{array}{c}* \\
{[16]}\end{array}$ \\
\hline & & & & Phase out of GLP for heating purposes to 2027 . & \\
\hline & & Transport & $\begin{array}{l}\text { Private and } \\
\text { Public }\end{array}$ & $\begin{array}{l}\text { Further retrofit of gasoline and diesel engines to CNG to } 5.2 \text { million } \\
\text { vehicles in the timeframe. }\end{array}$ & $*$ \\
\hline & & $\begin{array}{l}\text { Manufacture } \\
\text { Mining }\end{array}$ & $\begin{array}{l}\text { Process } \\
\text { heating }\end{array}$ & Replacement of diesel, firewood and kerosene by natural gas. & [16] \\
\hline
\end{tabular}




\begin{tabular}{lllll} 
Combined & All & All & $\begin{array}{l}\text { Scenario that combines Optimist Energy Efficiency and Fuel switch } \\
\text { scenario inputs. }\end{array}$ \\
\hline
\end{tabular}

Designed by the authors

\subsection{Modelling Sector by Sector}

This section describes the energy-use modelling, branch by branch, and the corresponding projections that support it. Each sector models the energy consumption according the National Energy Balance of Bolivia 20002014 description, BEN in spanish acronym [58].

\subsubsection{Residential}

The residential sector represented $18 \%$ of the total energy demand in 2012 with an average of $4 \%$ annual growth in the last decade. The fuel consumption in 2012 splits between LPG (40\%) and firewood (30\%), the remaining $30 \%$ are made up by electricity and natural gas [58]. Except electricity, all fuels are used for cooking food and, to a lesser extent, for heating water.

The residential sector was modelled using a bottom-up methodology, households were chosen as the unit of consumption. Projections of population, urbanization and family size were used to calculate the number of households. Identified energy uses are shown in Fig 1. Due to remarkable differences in energy consumption per household, the residential sector was sub-divided into urban and rural sub-sectors. In $2012,66 \%$ of the total households were urban and $34 \%$ rural. In the same year, electrified urban households accounted for $95 \%$ of the total urban households (resp. 58\% in rural areas) [59]. It is expected that the country will reach $100 \%$ electrification by 2025 in both urban and rural settings [25].

\section{Lighting}

The technology options in electrified households include: HPS, CFL, Halogen and LED lamps. The technology share was assumed from [60]. The energy intensity calculations consider 4 bulbs for urban households and 3 for rural with a daily use of 4.5 and 3 hours respectively. The number of lamps/household is assumed to increase to 6 and 4 by 2035 for urban and rural households respectively. The aggregated electricity consumption for lighting accounts on average for $10 \%$ of the residential electricity demand and is thus comparable to data reported by [61].

\section{Appliances}

The lack of appliance ownership data for Bolivia makes end-use disaggregation complex. However a distinction in 2 tiers of consumption was included for both urban and rural households. The "Tarifa Dignidad" is a government subsidy since 2006 which covers $25 \%$ of the electricity fare for users with a monthly consumption of less than $70 \mathrm{kWh}$. In 2012, 38\% of urban users and $70 \%$ of rural users were registered in this low consumption tier. However, the percentage of users with access to this discounted fare has declined in the last 6 years representing $1.7 \%$ and $0.3 \%$ fewer beneficiaries in urban and rural areas respectively. This information was used to project linearly the number of users in the low tier of electricity consumption.

Projections of residential electricity demands as a function of GDP to 2022 were used from a study carried out by [24]. The energy use per urban households with the normal electricity fare was calculated for each year using Eq.1:

$$
\left[\begin{array}{c}
\text { Energy use per } \\
\text { urban hh with } \\
\text { normal fare }
\end{array}\right]_{y}=\frac{\left[\begin{array}{c}
\text { Urban electricity } \\
\text { demand, } k W h / \text { month }
\end{array}\right]_{y}-\left[\begin{array}{c}
\text { Urban } h h \text { with } \\
\text { special fare }, h h
\end{array}\right]_{y}^{* 70 ~} \mathrm{kWh} / \mathrm{hh} \cdot \mathrm{month}}{[\text { Urban hh with normal fare, } h \mathrm{hh}]_{y}}
$$

The energy use per urban households with the special fare was assumed constant and equal to $70 \mathrm{kWh} / \mathrm{hh}$ month. The calculation of energy intensity for electric appliances was carried out by subtracting the electricity consumed in illumination from the total electricity consumption per household. For rural users, data for electricity consumption from Rural Peru was used from [62].

\section{Cooking}


Though the share of traditional biofuels has declined in the last decade, biomass participation remains strong in the total energy consumption. In 2012, $17 \%$ of the total households did not have access to clean cooking facilities [17]. The open fires used are fairly inefficient, consuming around 1.46 tons of wood per household each year and emitting significant amounts of smoke representing a health risk [63]. In parallel $83 \%$ of the population relies on gas (LPG and natural gas pipeline) for cooking purposes. According to 2012 data, $97 \%$ of urban and $57 \%$ of rural households use gas for cooking. For the model, the share of cook stove types was taken from [17] and targets for natural gas penetration by pipeline and LPG compression stations was assumed from [23]. Annual energy consumption per household for each technology type were taken from [64] and [63].

\subsubsection{Transport}

The transport sector was modelled using four subsectors: road, rail, flights and navigation. Different approaches were used to project their energy requirements depending on the data available.

\subsubsection{Road Transport}

Currently the largest and fastest growing energy consumer, the transport sector only uses oil derivatives, $73 \%$ of which are gasoline and diesel, while the rest is Compressed Natural Gas, CNG[58]. Bolivia is not a selfsufficient producer of diesel and gasoline, and not only import this fuels to supply domestic demand but also subsidise the cost.

Due a massive popular rejection in 2010 to the gradual subsidy removal, the current policy relies on annual targets of government-funded engine conversion from Gasoline and Diesel to CNG. Between 2000 and 2012 the EEC-GNV ${ }^{5}$ reported about 210 thousand vehicle transformations [53] raising the gas consumption share in the transport sector from $2.3 \%$ in 2000 to $21 \%$ in 2012 [58] and saving 250 million dollars in avoided subsidy [53].

Even though the fuel switch was a successful strategy to slow down the growing demand of liquid fossil fuels, it is only a partial solution to a major problem composed by the highly inefficient public transport system, the old vehicle fleet and the lack of initiative for an emissions mitigation legislation. Nevertheless, several projects of public transport massification starting in the capital city of La Paz are being carried out and meeting immediate popular acceptance.

To model the road transport, energy requirements it was sub divided into private, public and freight transport (Fig 1). Nearly 67\% of the fleet in circulation, is made up of cars for private transportation, wagons and jeeps (2012). Vehicles for public transport and heavy-duty trucks account for 9\% and $24 \%$ of the fleet respectively. Each sub-sector was modelled separately using different approaches.

\subsection{Private Transport}

A bottom-up approach was used for modelling the private transport. The energy consumption of the fleet of vehicles is calculated by Eq.2:

$$
\left[\begin{array}{c}
\text { Energy } \\
\text { Consumption }
\end{array}\right]=\left[\begin{array}{c}
\text { Stock of } \\
\text { vehicles }
\end{array}\right] \cdot\left[\begin{array}{l}
\text { Annual } \\
\text { Vehicle } \\
\text { mileage }
\end{array}\right] \cdot\left[\begin{array}{c}
\text { Fuel } \\
\text { economy }
\end{array}\right]
$$

Vehicle stock by type and fuel use were taken from the national transport registry for 2012 [65]. The private fleet expansion was calculated each year using a vehicle ownership saturation function described in[66]. In this study a cross-section analysis of 45 developed and developing countries was used to determine an equation which determine the vehicle per capita as a function of per capita income. The vehicle per capita increases at the lowest income level and slows down as saturation is approached. Eq. 3 and Eq.4 describe the vehicle Stocks calculations:

$$
V_{t}=\gamma \cdot e^{\alpha \cdot e^{\beta \cdot G D P t}}+(1-\theta) * V_{t-1}
$$

\footnotetext{
${ }^{5}$ Executing Agency for Gas conversion
} 


$$
\text { Stock }_{t}=\left(P_{t} \cdot V_{t}\right) / 1000
$$

Where $V_{t}$ denote the vehicle ownership (in vehicles per 1000 person), $t$ is the calendar year, GDP is the GDP per capita in and $P$ is the population. Table 3 summarises the country-group parameters used for the projection of private vehicles fleet $(v)$ and motorcycles $(m)$.

Table 3. Parameters used in econometric model

\begin{tabular}{lll}
\hline Parameter & Value & Description \\
\hline $\mathrm{V}_{2012, \mathrm{v}}$ & 62.707 & Vehicle Ownership in base year \\
$\mathrm{V}_{2012, \mathrm{~m}}$ & 15.344 & \\
$\gamma_{\mathrm{v}}$ & 80 & Vehicle ownership saturation level to 2035 \\
$\gamma_{\mathrm{m}}$ & 30 & \\
$\theta_{\text {increase }}$ & 0.095 & Speed of adjustment, increase \\
$\theta_{\text {decrease }}$ & 0.084 & Speed of adjustment, decrease \\
$\alpha$ & -5.897 & Curvature parameter alpha \\
$\beta_{\mathrm{v}}$ & -0.24 & Curvature parameter beta \\
$\beta_{\mathrm{m}}$ & -0.13 & \\
\hline
\end{tabular}

Private vehicles split between light duty and Wagon \& Jeeps. The share between both vehicle types changed in the last two decades according the fleet registration. Based in this data, the 2035 share was assumed to change linearly from $39 \%$ and $61 \%$ in 2012 to $44 \%$ and $56 \%$ to 2035 for light duty and Wagon \& Jeep vehicles respectively.

Finally, the vehicle mileage is the annual distance travelled by each vehicle and the fuel economy is the average energy consumed per distance travelled. A constant mileage of $6000 \mathrm{~km} / \mathrm{yy}$ was used for motorcycles, 12000 $\mathrm{km} / \mathrm{yy}$ for Light vehicles and $13000 \mathrm{~km} / \mathrm{yy}$ for Wagon and Jeeps. Vehicle fuel economy is detailed in Annex.

\subsection{Public Transport}

This category includes the transport modalities: taxi, minibus, microbus, omnibus and coach buses. Alternative transport such as cableway and train were added separately in the High GDP scenario. The passenger-km (pkm), was used as unit of energy consumption. The energy requirements were calculated by multiplying the pkm by the energy intensity.

Energy intensities were calculated in energy per pkm basis using specific engine requirements by type of engine (energy per kilometre), average annual distance travelled and average number of passenger per travel [67] [68] (See Annex). The annual pkm transport demand was calculated for the base year adding the pkm of all transport modalities. For each transport modality the pkm is calculated by multiplying the stock [65], the average number of passengers in each travel and average annual distance travelled [69]. Projections for pkm were calculated using a simple autoregressive model. An elasticity was calculated using 15 years of data and represents the percentage variation in the pkm for each $1 \%$ increase in the GDP (Eq. 5).

$$
p k m_{t}=p k m_{t-1} *\left(1+e \cdot G_{G D P}\right)
$$

Where: $p k m$ is the passenger-km, $G_{G D P}$ is the growth rate of Gross Domestic Product. The elasticity, $e$, was adjusted using the Least Squared regression Method using the software E-Views 7 [70] using time series [58] from 2000 to 2012. ( $\mathrm{e}=1.0495$, $\mathrm{P}$-value $=0.000<0,1, \mathrm{R}^{2}=0.9898=\sim 1, \mathrm{DW}=1.6422=\sim 2$, Std. Error=0.1226= 0).

\subsection{Freight Transport}

The registered road-freight vehicles in Bolivia has grown by $450 \%$ in the last 20 years [65]. Based on the average distance travelled, it was sub divided into urban freight and inter-urban freight.

The energy consumption was calculated multiplying the annual freight tonne-km transport (tkm) by the energy consumed per tkm for each freight transport modality. Similarly to public transport, the annual tkm was calculated for all technologies by multiplying the stock, load capacity and average distance travelled per year. Energy intensities are summarised in Table A.1 in Annex. 
The growth of freight transport is mainly linked to the rise of agricultural, mining and manufacture activities. Therefore, the annual volume of freight activity was projected to 2035 using Eq.6 adapted from [71]. The elasticity was calculated using 20 years of historical data and represent the percentage variation in the number of volume of goods transported for each $1 \%$ increase in the GVA of manufacture, minerals and agricultural [72].

$$
\text { Tonne }_{t}=\text { Tonne }_{t-1} \cdot\left(1+e \cdot G_{a g}\right)
$$

Where: Tonne represents the annual volume of goods transported, $G_{a g}$ is the aggregated growth of manufacture, minerals and agricultural GVA between the years $\mathrm{t}$ and $\mathrm{t}-1, e$, is a constant adjusted using the Least Squares Method (e=0.0159, P-value $=0.0289<0.1, \mathrm{R}^{2}=0.9228=\sim 1, \mathrm{DW}=1.4903=\sim 2$, Std. Error $=0.0065=\sim 0$ ).

To calculate the freight transport activity, tkm, an average annual distance travelled of 70, 400 and $500 \mathrm{~km}$ for the transport modalities pickup-truck, truck and tract-truck were assumed. Energy intensities were calculated using fuel economy data from [73] and are showed in Appendix.

\subsubsection{Rail Transport}

Two railways were built in the decade of $80^{\text {th }}$ to impulse minerals and agricultural trade to the western and the eastern markets respectively, both are not interconnected.

The pkm was selected as unit of energy consumption. Because both railways transport different type of goods, andean (A) railways transport mainly minerals and oriental $(\mathrm{O})$ transport agricultural products). An elasticity with GVA was calculated based in 17 years of data [74] [75]. This elasticity represents the percentage variation in tkm for each 1\% increase in the GVA (Eq. 7 and 8). It was assumed that the railways will adapt for future transport requirements.

$$
\begin{aligned}
& t k m_{A, t}=t k m_{A, t-1} *\left(1+e_{A} * G_{G V A m, t}\right) \\
& t k m_{o, t}=t k m_{O, t-1} *\left(1+e_{O} * G_{G V A a, t}\right)
\end{aligned}
$$

Were tkm represents the annual tonne-km, $\mathrm{G}_{\mathrm{GVA}}$ represents the annual growth of the GVA related to activity between $\mathrm{t}$ and $\mathrm{t}-1,\left(\mathrm{e}_{\mathrm{A}}=0.36108, \mathrm{P}\right.$-value $=0.0212<0.1, \mathrm{R}^{2}=0.8527=\sim 1, \mathrm{DW}=2.0184=\sim 2$, Std. Error $\left.=0.0058=\sim 0\right)$ and $\left(\mathrm{e}_{\mathrm{O}}=0.39041, \mathrm{P}\right.$-value $=0.09210<0.1, \mathrm{R}^{2}=0.3904=\sim 1$, DW=2.0536= 2, Std. Error=0.2304= 0) are the adjusted elasticities. Energy intensities are detailed in Annex.

\subsubsection{Aviation}

Database records of passengers, freight, fuel consumption and route mileage records from 2001 to 2012 were used to model the energy requirements. Using pkm a distinction was made between international and local flights. A constant average growth of 5.76\% based on data from 2000-2011 was used to project international flights pkm.

According to a study of the aviation sector over 213 countries [76], the increase of national income is directly related to the growth of the aviation service. Therefore, to project the local aviation pkm an elasticity with GDP was calculated according to Eq.9.

$$
p k m_{t}=p k m_{t-1} *\left(1+e * \mathrm{G}_{G D P}\right)
$$

Where: pkm are the annual passenger-km of local flights, $t$ is the calendar year, $\mathrm{GDP}_{\mathrm{t}}$ is the annual growth of Gross Domestic Product between $\mathrm{t}$ and $\mathrm{t}-1$ and $e$ is the elasticity $(\mathrm{e}=1.315576$, P-value $=0.0978<0.1$, $\mathrm{R}^{2}=0.6708=\sim 1, \mathrm{DW}=2.4383=\sim 2$, Std. Error $=0.712138=\sim 0$ ). Energy intensities are detailed in Annex.

\subsubsection{Water transport}

Represents a small portion of the transport sector with a participation of $0.04 \%$ in the total energy consumption of transport in 2012. It accounts for the fuel consumption of boats. The diesel consumption for water transport declined from 8200 bbls in 2003 to $7000 \mathrm{bbl}$ in 2011 [72]. A constant energy intensity of 10.544 thousandth bep/tonne was assumed and annual growth of $1.5 \%$. 


\subsubsection{Massive transport}

Several projects for massive transport has been planned in the investment portfolio of the Economic and Social Development Plan 2016-2020, PDES [19]. In 2013, the cableway project in La Paz with a capacity of 18 thousand of passengers per hour added an additional electricity demand of $21 \mathrm{GWh}$. [25]. Only this project has been added to the Reference scenario. Foreseen energy demands for long term projects were included in the High GDP.

\subsubsection{Industry}

According to the Competitive Industrial Performance (CIP), Bolivia is in the 4th quintile ranking with the least industrialized economies worldwide (92/135 CIP index) [77]. Nevertheless the industrial sector represents the second largest energy consumer in Bolivia after transport and before residential sectors.

A combination of bottom-up and top-down methodologies were used to project the energy consumption in each sub-sector and further disaggregation by end-use was used to insert policy targets. The structure is shown in Fig 1 and scenario assumptions are detailed in Table 2.

\subsubsection{Manufacture}

The manufacture captures $82 \%$ of the energy consumption of all industrial sub-sectors [78]. This includes all activities related to: production of foods and beverages, textile, leather, metallic, non-metallic products and other manufacture activities.

Historically the manufacture sector had limited level of mechanization and single product dependency. According to 2006 data, microenterprise and family size units employed the $83 \%$ of workers but only produced 25\% of the total manufacture income [79]. However, according to the macroeconomic projections, the contribution of manufacture to GDP will increase to 2025, this translates into mechanization and gradual increase of average enterprise size.

Monetary energy intensities were used to model each sub-sector using data of energy consumption by enterprise size from [78]. A weighted average between micro-small and medium-large scale manufacture energy intensity was used in the base year. Author's assumptions of manufacture size distribution are detailed in Table 4 and Energy intensities are summarised in Appendix.

\begin{tabular}{lllll}
\multicolumn{3}{l}{ Table 4. Manufacture enterprise size share assumptions } \\
\hline Branch & \multicolumn{2}{l}{ Micro-small } & \multicolumn{2}{l}{ Medium-large } \\
\hline & 2012 & 2035 & 2012 & 2035 \\
Foods and beverages & $2 \%$ & $1 \%$ & $98 \%$ & $99 \%$ \\
Textiles & $65 \%$ & $60 \%$ & $35 \%$ & $40 \%$ \\
No metallic & $40 \%$ & $35 \%$ & $60 \%$ & $65 \%$ \\
Metallic & $5 \%$ & $2 \%$ & $95 \%$ & $98 \%$ \\
Other & $20 \%$ & $15 \%$ & $80 \%$ & $85 \%$ \\
\hline
\end{tabular}

\subsubsection{Cement}

A bottom-up methodology was used to determine future energy demands of the cement industry. Energy end use per tonne of cement produced was used from [80]. Annual volume of cement production, tonne/yy, was used as unit of consumption and projected as function of construction-GVA growth between $t$ and $t-1$. Data from 1995-2012 was used to estimate the elasticity [81] described in Eq. 10 (e=0.9991, P-value=0.0001<0.1; $\mathrm{R}^{2}=0.9391=\sim 1 ; \mathrm{DW}=2.4297=\sim 2$; Std Error= 0.021866= 0).

$$
T_{t}=T_{t-.1}\left(1+e \cdot G_{G V A, \text { construction }, t}\right)
$$

\subsubsection{Commercial Sector}

The energy consumption in the commercial sector grew $10 \%$ between 2000-2012 and is composed by $30 \%$ natural gas and 70\%LPG in 2012 [58]. A top-down modelling approach was used to project final energy consumption. Assumptions for disaggregation of electric and fuel end-uses was taken from [54] and is shown in Fig 1. Energy intensity calculations are detailed in the Appendix. 


\subsubsection{Mining and Quarrying}

The main products extracted are zinc, lead, tin and cooper ores. Metallurgy activities in Bolivia are scarce however. Around 3.4\% of the total metal ore extracted is refined [81]. Energy requirements for metal refining was not considered in this study.

Production volume and energy use information from the mining survey was used to estimate the average energy intensity for the production of zinc, lead, tin and copper (see Appendix). Due the production of minerals is not related with any economic activity but programed expansions, projections of mineral production were based in scheduled mine expansions detailed in [25].

\subsubsection{Agriculture}

The main economic activity of rural population, which includes activities related to farming, fishing and hunting. During the period of economic growth 2000-2012 the farming sector grew favoured by the rise of the international price of soy, sunflower and sugar cane [82]. In this period, the cultivated area increased in $40 \%$, the cereal exports in 54\% and the energy intensity grew annually by 5.34\%. However, to 2012 the energy intensity of agriculture remains lower compared with the LAC average.

The farm size (hectare) was used as a proxy for irrigation and machinery related energy consumption. Secondary information from [83] [84] [58] was used to estimate the end-use energy intensities for irrigation and machinery (See Appendix).

\section{Results}

This section discusses the findings for the baseline and the 3 alternative scenarios from 2012 to 2035 . Historical data since 2000 has been included to better visualize the evolution of each energy indicator.

\subsection{Reference Scenario}

The business as usual scenario shows an average growth rate of energy and electricity consumption of $3.77 \%$ a.a. and $5.23 \%$ a.a. respectively. To 2035 the energy and electricity demand grew $134 \%$ and $223 \%$ compared to 2012. Notice that demand calculations exclude the energy requirements for electricity generation and exports. Fuel mix participation drops from 43\% fossils and 15\% biomass in 2012 to 39\% and 10\% respectively in 2035. Conversely, the share of Gas and Electricity increases from 32\% and 10\% to 36\% and 14\% in 2035. Fig 2 shows the energy demand projections by sector. Sectors which dominate the national energy consumption in 2035 are transport, industry, and residential with a respective percentage of: 39\%, 34\% and 13\%.

Figure 2. Results of Energy demand projections by sector.

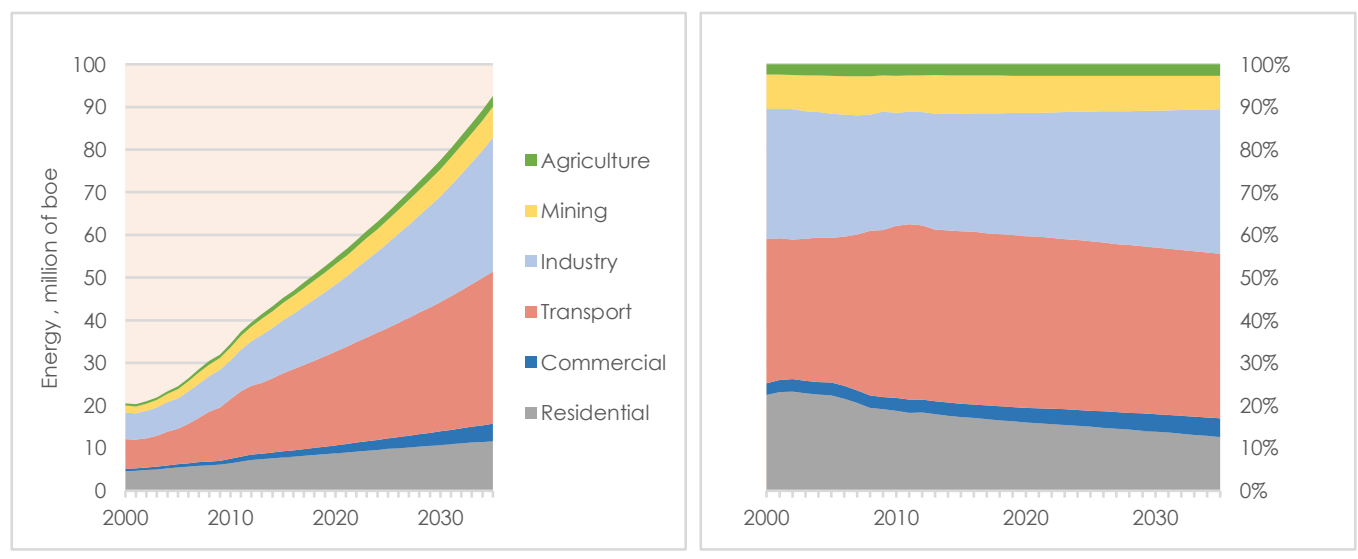

Overall energy intensity tends to increase at early and intermediate stages of industrialization, and to decrease as the structure shifts from energy-intensive raw material processing towards more skill intensive industries 
with products of higher revenues [85] [3]. On a per unit of GDP basis, aggregated energy intensity follows this inverted curve, increasing to its maximum in 2012 before dropping back to the initial value by 2035 . Driving forces for this improved energy intensity include the increased revenues in industry and mining and an expected higher growth rate of the GDP compared to overall energy consumption. Conversely, energy consumption per capita increases along with the steadily shift of the Bolivian society to a more industrialized economy. (Fig 3).

Figure 3 Aggregated energy intensities from 2000 to 2035

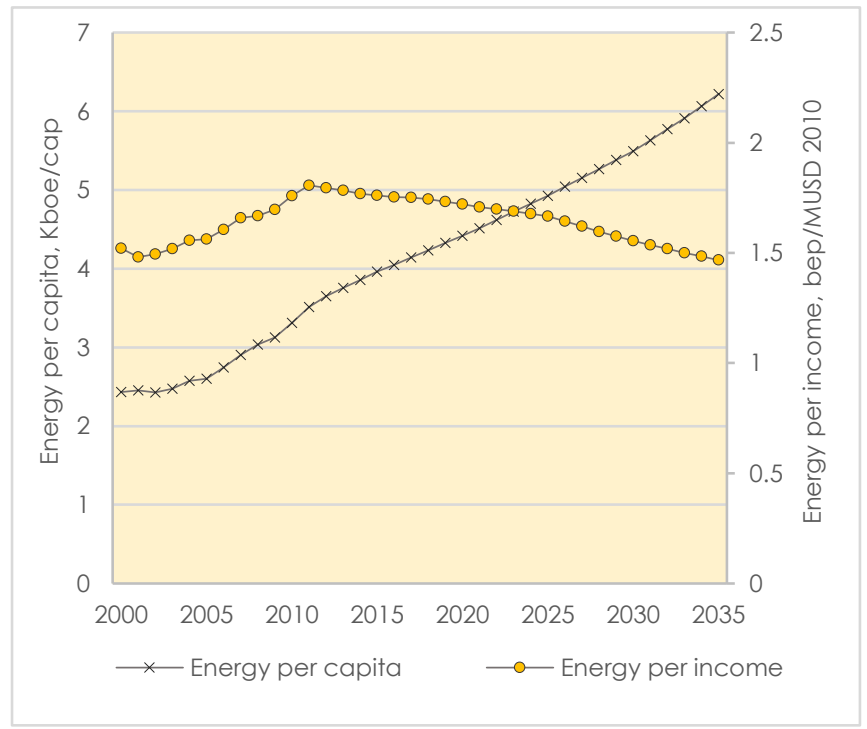

From a final use perspective, energy consumption was grouped into illumination, electrical uses, heat, motive, passenger transportation and freight transportation. Table 5 shows the energy consumption of all the aforementioned energy uses for 2012 and 2035 for the reference scenario.

Table 5 Energy demand by end-use activity

\begin{tabular}{lrrrr}
\hline & \multicolumn{2}{c}{ Energy, kboe } & \multicolumn{2}{c}{ Share, \% } \\
\cline { 2 - 5 } End-use & $\mathbf{2 0 1 2}$ & $\mathbf{2 0 3 5}$ & $\mathbf{2 0 1 2}$ & $\mathbf{2 0 3 5}$ \\
\hline Ilumination & 712 & 1906 & $1.8 \%$ & $2.1 \%$ \\
Electrical uses & 3420 & 11259 & $8.6 \%$ & $12.2 \%$ \\
Heat & 17677 & 39869 & $44.7 \%$ & $43.1 \%$ \\
Motive & 1579 & 3884 & $4.0 \%$ & $4.2 \%$ \\
Motive- passengers & 10858 & 24549 & $27.5 \%$ & $26.5 \%$ \\
Motive- freight & 5292 & 11102 & $13.4 \%$ & $12.0 \%$ \\
\hline Total & $\mathbf{3 9 5 3 7}$ & $\mathbf{9 2 5 6 9}$ & $\mathbf{1 0 0 \%}$ & $\mathbf{1 0 0 \%}$
\end{tabular}

Vehicle ownership projections foresee 1.61 million private vehicles in 2035 . This number duplicates the private vehicle fleet in 2012. From an activity perspective, the pkm travelled for all transport modalities grows in 99\% in 2035 compared with 2012. For all modalities of freight transport, the tkm, grows in 100\% in 2035 compared with 2012. Note that the transport projections depends on income and population and exclude the impact of other variables such fuel price and subsidy variations.

\subsection{Sensitivity Analysis}

Long term projections use parameters which are uncertain in future. This might contribute to the uncertainty in the projections results. Given that most of the units of energy consumption in our model use GDP or GVA as parameter, a simple method was used to determine the parameter sensitivity of the energy model for each sector. The difference in the model output was calculated by varying the input parameter from a pessimistic scenario to an optimistic scenario. 
Each macroeconomic scenario was modelled using a Computable General Equilibrium model, CGE, which estimates future annual growths of GDP and sectorial GVA. The Reference scenario assumes a regular public investment deduced from time series data. A high GDP scenario models the maximum public investments in selected productive projects with specific energy requirements; such investments are envisioned to generate positive shocks in the economy (high GDP growth). A summary of the productive projects included in the High GDP scenario are described in Table 6, both planned energy demands and investments were added in the energy and CGE models. Finally, a low GDP scenario was modelled assuming a lower public investment compared to the reference scenario. Due the energy model links all its units of consumption with the macroeconomic scenario, it is expected that the projected energy consumption grows accordingly to the economic growth scenario. However, the parameter sensitivity varies between sector and sector. In this sense, a sensitivity index, SI, was calculated each year to provide an indication of parameter sensitivity to all sectors: $S I=\left(D_{\text {high }}-\right.$ $\mathrm{D}_{\text {low }} / \mathrm{D}_{\text {ref. }}$. The average SI for the modelled period from 2012-2035 are summarized for each sector in Table 7.

Table 6. Energy demands of foreseen projects included in the High GDP scenario.

\begin{tabular}{|c|c|c|c|c|}
\hline Sector & Project & Start-up & Energy requirements & Reference \\
\hline Transport & Electric train & $2016-2020$ & Electricity: $1822 \mathrm{GWh} /$ year & [25] \\
\hline \multirow[t]{7}{*}{ Industry } & Iron Steel & Phase I: 2018 & Phase I: 23 thousand Tonnes/ year & [19], \\
\hline & & Phase II: 2030 & Phase II: 2080 thousand Tonne/year & [23] and \\
\hline & & & Electricity: 0.2213 boe/tonne & {$[25]$} \\
\hline & & & Natural Gas: 2.6166 boe/tonne & \\
\hline & Urea ammonia & 2016 & Electricity: $181 \mathrm{GWh} /$ year & \\
\hline & & & Natural Gas: 3247 Kboe/year & \\
\hline & Ethylene-Poliethylene & 2016-2020 & Electricity: 53 GWh/year & \\
\hline \multirow[t]{6}{*}{ Mining } & Lithium carbonate & Phase I: 2020 & Phase I: 250 tonne/year & [25] \\
\hline & & Phase II: 2025 & Phase II: 480 tonne/year & \\
\hline & & & Electricity: $0.6208 \mathrm{GWh} /$ tonne & \\
\hline & & & Natural Gas: 0.667 kboe/tonne & \\
\hline & Lead & 2022 & 23 thousand tonne/year & \\
\hline & Cooper & & 140 thousand tonne/year & \\
\hline Agriculture & $\begin{array}{l}\text { Several agro-industrial } \\
\text { projects }\end{array}$ & $2016-2025$ & Electricity: $6.4 \mathrm{GWh} / \mathrm{year}$ & {$[25]$} \\
\hline
\end{tabular}

A SI index of 1 indicates a high parameter sensitivity of the energy model to changes in the economic parameters. The sensitivity analysis shows the SI is higher for the sectors which foresee large energy intensive investments in the High GDP scenario such as Industry, Mining and Transport. Figure $\mathbf{4}$ compares in a higher level the aggregated energy intensity for all GDP scenarios. The analysis shows that important investments not only have an impact in the economy but in the energy intensity of the system, while small changes do not. A gradual reduction of the energy intensity means higher revenues for each economic activity, which is consistent with the transformation of Bolivia towards a more industrialized economy.

Table 7. Sensitivity Index per sector

\begin{tabular}{lr} 
Sector & SI \\
\hline Residential & 0.05 \\
Commercial & 0.03 \\
Transport & 0.20 \\
Industry & 0.36 \\
Agriculture & 0.02 \\
Mining & 0.26 \\
\hline
\end{tabular}

Figure 4 Energy intensity comparison and GDP scenarios. 

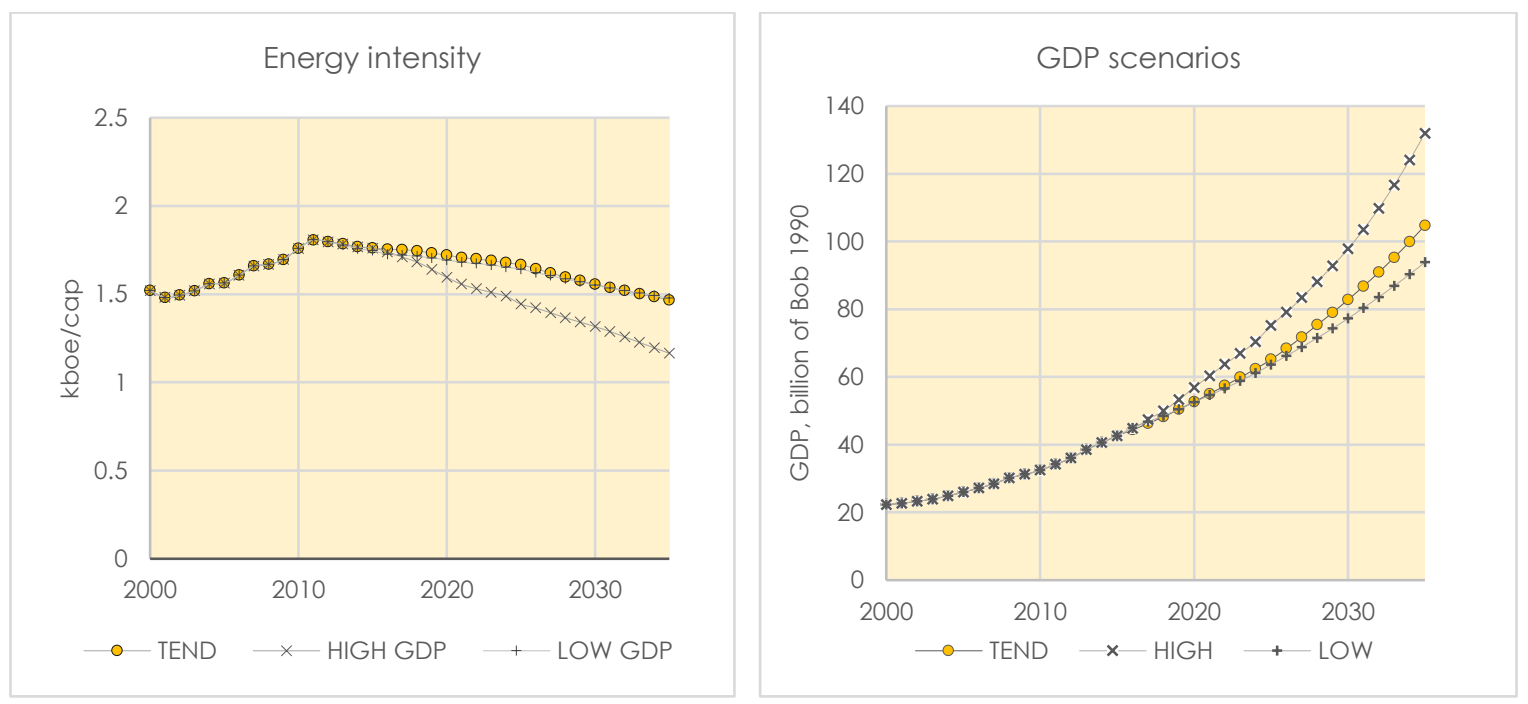

\subsection{Alternative Scenarios}

This section analyses the effect of different policies and measures in three energy scenarios. In the primary axis, Fig 5 compares the energy intensity of the ES scenario with the REF scenario showing a reduction in $7.8 \%$ in 2035. In the secondary axis of Fig 5, domestic consumption of Natural Gas between the FS scenario and REF are compared showing a $12 \%$ increase of Natural Gas consumption by 2035, showing the results of fuel substitution.

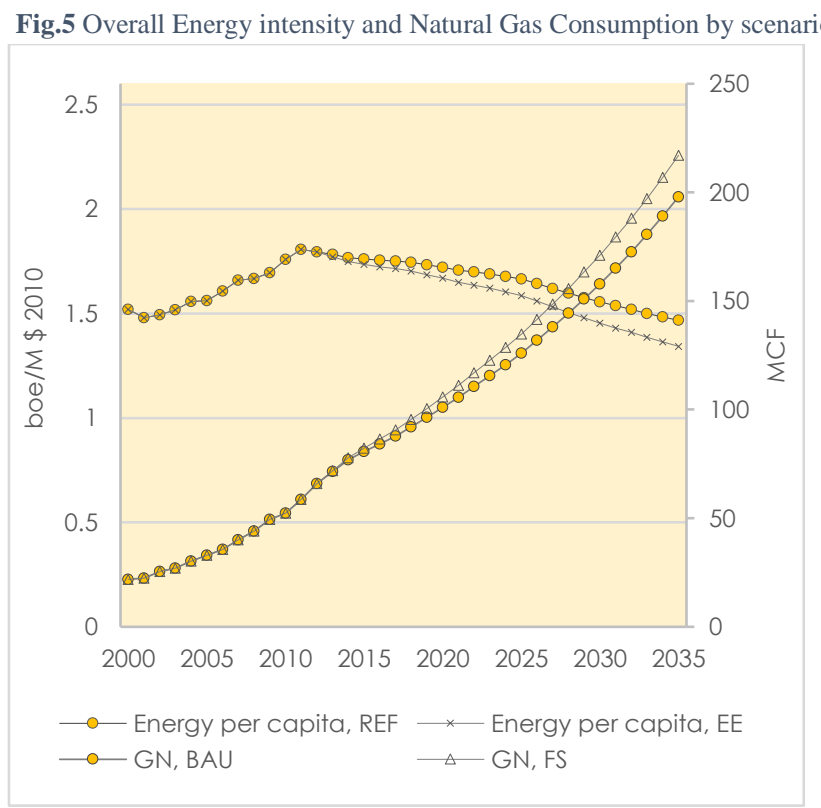

Greenhouse gas emissions, GHG, were modelled for each fuel using average values from the IPCC database. Emissions were related to a specific technology or energy use, including carbon dioxide, methane and nitrous oxide[26]. Units of metric tonnes of $\mathrm{CO} 2$ equivalent were used to measure and compare the GHG emissions between scenarios. Fig 6 compares the annual emissions saved for the ES, FS and COMB scenarios compared against the REF scenario. Major pollutant savings are obtained in the combined scenario which captures the energy policies and measures from the other two scenarios.

Figure 6 Emissions savings by scenario compared against Reference scenario 


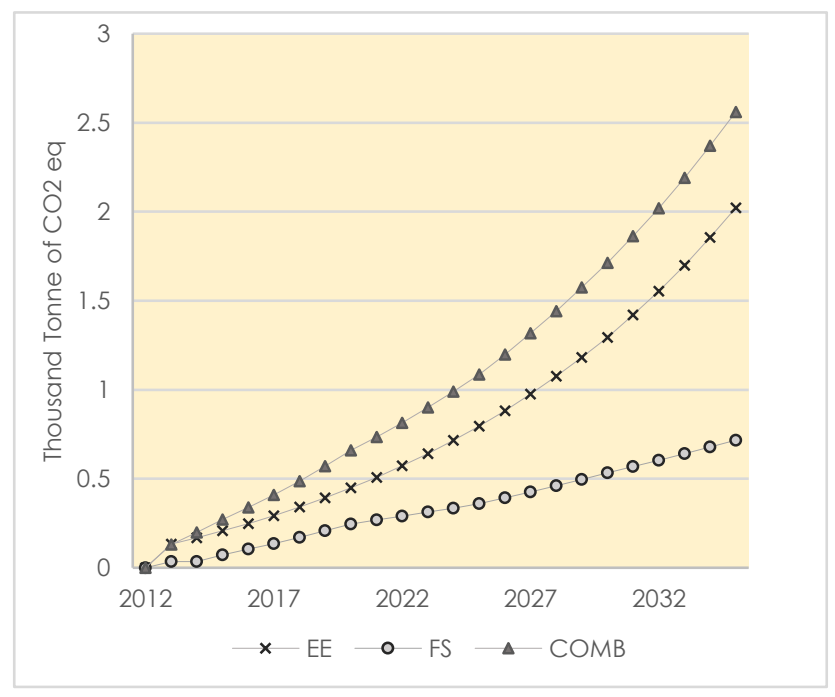

Aggregated savings in energy, electricity and emissions are summarized in Table 8. A decomposition of energy demand by end use group is presented in Table 9 for the base year and for the REF scenario. Energy savings in 2035 for the ES, FS and COM scenarios are presented compared with the REF scenario. The percentages were calculated by the relation $\left(\right.$ Demand $_{\text {REF }}-$ Demand $_{\text {scenario }}$ )/ Demand $d_{\text {REF }}$.

Table 8. Aggregated savings in the period 2012-2035 for each scenario compared against Reference Scenario

\begin{tabular}{lllll} 
Variable & Units & ES & FS & COMB \\
\hline Emissions $\mathrm{CO}_{2}$ eq & MTons & 19 & 8 & 26 \\
Energy & Mboe & 75 & 13 & 82 \\
Electricity & GWh & 26353 & -20960 & 6197 \\
\hline
\end{tabular}

Table 9. Energy consumption by end-use classification for Reference, Energy Savings, Fuel Substitution and Combined Scenario in kboe.

\begin{tabular}{|c|c|c|c|c|c|c|c|}
\hline Sector & Subsector & $\begin{array}{l}\text { Energy use } \\
\text { clasification }\end{array}$ & $\begin{array}{l}\text { Base } \\
\text { year } \\
2012\end{array}$ & $\begin{array}{c}\text { REF } \\
\text { scenario } \\
2035\end{array}$ & $\begin{array}{c}\text { ES } \\
\text { scenario } \\
2035\end{array}$ & $\begin{array}{c}\text { FS } \\
\text { scenario } \\
2035\end{array}$ & $\begin{array}{c}\mathrm{COM} \\
\text { scenario } \\
2035 \\
\end{array}$ \\
\hline \multirow[t]{3}{*}{ Residential } & Lighting & Lighting & 282 & 537 & $-36.2 \%$ & $0.0 \%$ & $-36.2 \%$ \\
\hline & Cooking & Heat & 5718 & 7165 & $-5.2 \%$ & $-3.5 \%$ & $-6.8 \%$ \\
\hline & Appliances & Electrical & 1265 & 3961 & $-11.4 \%$ & $0.0 \%$ & $-11.4 \%$ \\
\hline \multirow[t]{5}{*}{ Industrial } & Cement & Electrical & 202 & 1095 & $-14.9 \%$ & $0.0 \%$ & $-14.9 \%$ \\
\hline & & Heat & 1518 & 8246 & $-20.0 \%$ & $0.0 \%$ & $-20.0 \%$ \\
\hline & Manufacture & Electrical & 907 & 3217 & $-6.2 \%$ & $-3.8 \%$ & $-9.9 \%$ \\
\hline & & Heat & 7280 & 17470 & $-6.2 \%$ & $-4.3 \%$ & $-10.3 \%$ \\
\hline & & Motive & 565 & 1420 & $-6.0 \%$ & $-11.4 \%$ & $-16.7 \%$ \\
\hline \multirow[t]{2}{*}{ Mining \& Quarrying } & All & Electrical & 552 & 1410 & $-7.2 \%$ & $58.4 \%$ & $44.7 \%$ \\
\hline & & Heat \& Motive & 2875 & 5819 & $-10.6 \%$ & $-14.2 \%$ & $-23.2 \%$ \\
\hline \multirow[t]{2}{*}{ Agriculture } & All & Electrical & 3 & 21 & $-12.4 \%$ & $33.3 \%$ & $16.8 \%$ \\
\hline & & Motive & 1014 & 2464 & $-1.8 \%$ & $-0.8 \%$ & $-2.5 \%$ \\
\hline \multirow[t]{3}{*}{ Commercial } & All & Lighting & 242 & 766 & $-23.0 \%$ & $0.0 \%$ & $-23.0 \%$ \\
\hline & & Electrical & 491 & 1555 & $-23.0 \%$ & $41.4 \%$ & $14.6 \%$ \\
\hline & & Heat & 286 & 1169 & $-20.0 \%$ & $-22.9 \%$ & $-38.3 \%$ \\
\hline Services & Street Lighting & Lighting & 188 & 603 & $-4.7 \%$ & $0.0 \%$ & $-4.7 \%$ \\
\hline \multirow[t]{6}{*}{ Transport } & Private & Passenger & 5819 & 9901 & $-5.2 \%$ & $0.5 \%$ & $-4.9 \%$ \\
\hline & Public & Passenger & 4080 & 11016 & $-7.9 \%$ & $-4.7 \%$ & $-9.5 \%$ \\
\hline & Freight & Load & 5224 & 11006 & $-3.8 \%$ & $0.0 \%$ & $-3.8 \%$ \\
\hline & Rail & Passenger \& Load & 67 & 86 & $-12.2 \%$ & $0.0 \%$ & $-11.0 \%$ \\
\hline & Aviation & Passenger \& Load & 959 & 3632 & $-6.6 \%$ & $0.0 \%$ & $-6.6 \%$ \\
\hline & Navigation & Passenger \& Load & 7 & 10 & $0.0 \%$ & $0.0 \%$ & $0.0 \%$ \\
\hline
\end{tabular}




\begin{tabular}{|c|c|c|c|c|c|c|c|}
\hline & Massive & Passenger\&Load & 0 & 13 & $0.0 \%$ & $0.0 \%$ & $0.0 \%$ \\
\hline Total demand & & & 39544 & 92581 & $-8.5 \%$ & $-1.5 \%$ & $-9.4 \%$ \\
\hline
\end{tabular}

The COMB scenario shows 82 million of boe of energy saved in 2035. Fig 7 illustrates the share of energy savings by policy group in 2035. Efficient heat use and eco vehicle driving are the policies with higher energy savings accounting by $79 \%$ of the total savings. The sectors which concentrate major energy savings in the COMB scenario are the industrial sector with a share of $48 \%$, followed by transport with $25 \%$ and residential with $13 \%$.

According to the model results, a list of energy indicators for 2000, 2012 and projections to 2035 were calculated and compared with values in 2000 (Figure 8). Energy per income and emissions per energy consumed are the indicators which decrease while energy per capita, electricity per capita, emission per capita tends to increase.

Figure 7. Energy savings share by policy group in 2035. Reference scenario against Combined scenario. Energy units in Kbep

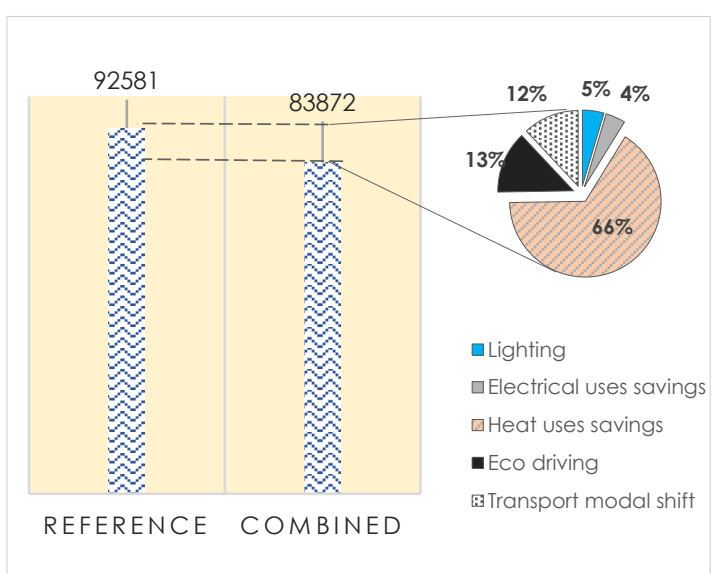

Figure 8. Summary of projected Energy Indicators for the Reference scenario

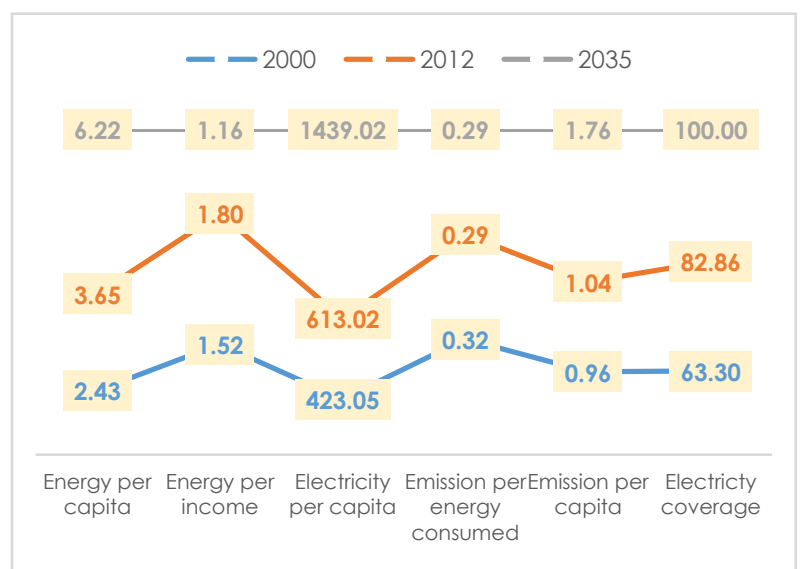

\section{Discussion}

The complexity of energy demand patterns is linked to the economic development and energy intensification which are not growing at the same speed between the economy sectors. This study models these sources of randomness in a decentralized energy model structure which captures the dynamics of each sector separately. Furthermore, external variables beyond the vegetative growth such as energy access and fuel mix change targets are included. Such external variables depend of political or institutional decision. In addition inter-sectorial analysis such as energy savings or fuel substitution require model framework with end-use detail which has been inserted according to the data available. Whereas all sectors were modelled using different approaches and assumptions, those differences might lead to insert different levels of uncertainty between sectorial projections.

The highlights of this methodology are the simplified and comprehensive tree structure developed within LEAP which facilitates the understanding and analysis of the energy system with a scenario space which allows to policymakers to explore alternative futures. The model proposed it is easy to update year by year and to be improved through new data of technology ownership. Since the energy model is not dependent of data availability, top-down modelling has been applied within specific units of consumption and cross-country information has been used to fill data requirements.

However, the energy intensities used in this study do not have a behavioural component and there is no certainty that values derived from historical data will remain valid to the long-term future. Similarly, targets for fuel and technology switch are assumed to be absolute and do not reflect the consumer "option value". The complexities 
of consumer option to predict the adoption of specific technologies requires a complete study of consumer and firm choices, to determine the portion of consumers which find a technology option cost-effective and a perfect substitute for one another [86].

Monitoring monetary-based energy intensities is important to measure progress in sustainability trends. A reduction of the energy intensity means improvements in the productive use of energy, by reducing the amount of energy consumed without affecting the economic activity and without decelerating the socio-economic growth. Moreover, energy savings reduce infrastructure investment, imported fuels and GHG emissions. Energy intensities follow different projected patterns between sector and sector, for the period 2012-2035, Transport and Mining have a decreasing pattern. Conversely, the sectors with upward energy intensity are residential, commercial, industry and agriculture.

\section{Alternative Scenarios}

Incursions in energy savings and efficiency has been supported by the government since 2008 through the promulgation of the Supreme Decree No 29466 in which the Article 1 approves the "National Program of Energy Efficiency" which supports the implementation of actions, policies and projects that seek the rational, efficient and effective use of energy. However, Bolivia stills in the first stages of measure and monitoring energy efficiency indicators and there is not a current energy efficiency policy in place. In July of 2014 the Ministry of Energy and Hydrocarbons presented the "Plan for Energy Efficiency" [50] in which a national diagnosis was settle to define energy efficiency indicators and potential savings by sector. Nevertheless, most of the energy saving targets represent an aggregated potential with no technological detail or political instruments. In this regard, the energy model developed in this study aims to bring light to measure quantitatively the effect of structural drivers such as GDP growth and policy instruments such as energy saving or fuel substitution programs in the overall energy demand in Bolivia.

To remark, energy savings estimated in the ES scenario do not target the complete potential of energy efficiency measures, many other measures are applicable to technology-specific retrofit. For example the World Energy Investment Outlook 2014 [55] lists potential savings by sector through technological retrofit and efficient technology replacement. The dominant measures referred in this work consist in specific technology retrofit targets and energy savings through correct maintenance, good-practices and technology enhancement. Further technology performance instruments could be explored within a cost-benefit analysis to formulate politicallyacceptable energy policy

The sensitivity analysis, explores the energy demand boundaries under three macroeconomic scenarios. Due the inter-linkages between economy and energy, a CGE model was aligned. The analysis shows that the energy model is sensitive to variations in the GDP and GVA and the energy demand grows accordingly to the economic growth, however, the energy intensity remains almost constant under small variations in the economy scenario. The model shows that the foreseen public investments [19] will not only generate a positive impact in the economy but in the productive use of energy.

\section{Comparison of domestic Electricity demand projections with official projections}

Projections of electricity consumption were compared to official projections from the $\mathrm{CNDC}^{6}$ in the time horizon 2012-2025 [28]. In this report, an econometric method was used to estimate electricity demand using a Vector Error Correction model using GDP as endogenous variable. The projection excludes the off-grid demands. For instance, to compare with our model projections we excluded the rural residential and agricultural electricity demands. Differences between both projections are shown in Table 9.

Table 10. Comparison of electricity demand projections

\begin{tabular}{llll} 
& $\mathbf{2 0 1 5}$ & $\mathbf{2 0 2 0}$ & $\mathbf{2 0 2 5}$ \\
\hline POES, GWh & 7983 & 11042 & 15273 \\
LEAP, GWh & 7767 & 11944 & 14759 \\
Discrepancy & $2.7 \%$ & $8.2 \%$ & $3.4 \%$ \\
\hline
\end{tabular}

\footnotetext{
${ }^{6}$ National Committee for Load Dispatch
} 


\section{Conclusions}

This paper compiles in a comprehensive model structure information from several databases, diverse national, sectorial and firm survey efforts, ministerial reports for industrial, refinery, electric and economy and variety of studies focalised on single sectors and sub-sectors represented in one energy model. The main objective of this research is to generate a model which represent the energy demand in Bolivia and to develop a tool for energy planning. Additionally, our research illustrates the advantages of end-use disaggregation to incorporate end-use policy and to isolate the main factors which affect the energy intensity of the entire system.

At the governance level, multi-disciplinary planning integrates economy, social, climate and energy in line with sustainable development. In this sense, a holistic and simplified methodology approach is recommended to fulfil the needs of policy making, providing understanding of the dynamics of energy, technology, economy and the effects of policy in the multiple sectors of the energy system.

Our energy model is a pragmatic and simple methodology that might help to project fuel requirements and study the dynamics in energy consumption trough the monitor of energy intensities. In addition, the scenario formulation shifts focus from energy projections to policy development. Three scenarios were evaluated in this study, but a wider range of scenarios are possible.

Furthermore, the model is easy to update in terms of economic growth and units of consumption and easy to improve using data of technology ownership. A complete bottom up energy model will contribute to further policy design and data of technology ownership and consumer behaviour studies might help to further monitor progress in energy efficiency targets.

Finally, monitoring energy indicators such as overall or sectorial energy intensities might help to follow the progress on future energy savings/measures/targets and will contribute to the continuous learning process of energy policy implementation in developing countries.

\section{References}

[1] M. Nilsson, P. Lucas, and T. Yoshida, "Towards an Integrated Framework for SDGs: Ultimate and Enabling Goals for the Case of Energy,” Sustainability, vol. 5, pp. 4124-4151, 2013.

[2] United Nations, "The future we want. In Proceedings of the Rio+20 United Nations Conference on Sustainable Development," p. 49, 2012.

[3] UNIDO, "Industrial development report 2011. Industrial energy efficiency for sustainable wealth creation capturing environmental, economic and social dividends.," p. 239, 2011.

[4] International Institute for Applied Systems Analysis, "Global Energy Assessment- Towards a Sustainable Future," 2012.

[5] G. Dahlgren and M. Whitehead, "Policies and strategies to promote social equity in health. Background document to WHO - Strategy paper for Europe," Arbetsrapport, 1991.

[6] A. Halff, B. K. Sovacool, and J. Rozhon, Eds., "Energy Poverty," Nov. 2014.

[7] A. D. Zepeda E., "Achieving sustainable development: the energy investment challenge. UNDESA Policy Brief No.43," New York, USA, 2014.

[8] V. R. Roehrl R., Montes M., "UNDESA Policy brief No. 33. Governments need to push for more energy efficient end-use technologies," 2014.

[9] I. Dyner, "Energy Modelling Platforms for Policy and Strategy Support," J. Oper. Res. Soc., vol. 51, no. 2, p. 136, Feb. 2000.

[10] P. P. Craig, A. Gadgil, and J. G. Koomey, "What can hystory teach us? A Retrospective Examination of LongTerm Energy Forecasts for the United States*," Annu. Rev. Energy Environ., vol. 27, no. 1, pp. 83-118, Nov. 2002.

[11] S. C. Bhattacharyya and G. R. Timilsina, "Energy Demand Models For Policy Formulation: A Comparative Study Of Energy Demand Models," Mar. 2009.

[12] S. Jebaraj and S. Iniyan, "A review of energy models," Renew. Sustain. Energy Rev., vol. 10, no. 4, pp. 281-311, 2006.

[13] "World development Indicators," p. 180, 2015.

[14] “Anuario Estadistico 2012,” p. 68, 2012. 
[15] "Informe de Politica Monetaria," 2014.

[16] "Plan de Desarrollo Energético 2008-2027," 2010.

[17] "Bolivia. Caracteristicas de población y vivienda," 2012.

[18] "Nueva constitucion del Estado Plurinacional de Bolivia," 2010.

[19] "Plan de Desarrollo Economico y Social 2016-2020," p. 187, 2015.

[20] M. M. Monrroy, "Consumo de Gas Natural en Bolivia: Una Aplicación del Sistema Cuadrático Casi Ideal de Demanda,” Rev. Análisis Económico - Econ. Anal. Rev., vol. 24, no. 2, pp. 3-33, 2009.

[21] R. Lizarazu and J. Aliaga Lordemann, "Escenarios de emisión de gases de efecto invernadero CO2 en el sector energético en Bolivia," Rev. Latinoam. Desarro. Económico, vol. 1, no. 19, pp. 77-98, 2013.

[22] A. Pareja, M. Hinojosa, and M. Luján, "Atmospheric Pollutant Release Inventory for the City of Cochabamba, Bolivia, 2008.," Acta Nov., vol. 5, pp. 344-373, 2012.

[23] "Plan Estratégico Corporativo (PEC) 2015-2019," 2014.

[24] “Plan óptimo de expansión del Sistema Interconectado Nacional 2012-2022,” p. 166, 2012.

[25] "Plan Electrico del Estado Plurinacional de Bolivia 2025," p. 149, 2014.

[26] C. . Heaps, "Long-range Energy Alternatives Planning (LEAP) system. [Software version: 2015.0.23] Stockholm Environment Institute.” Somerville, MA, USA, 2016.

[27] P. Meier, "Energy Systems Analysis for Developing Countries," vol. 222, 1984.

[28] L. Suganthi and A. A. Samuel, "Energy models for demand forecasting-A review," Renew. Sustain. Energy Rev., vol. 16, no. 2, pp. 1223-1240, 2012.

[29] F. Rogan, C. J. Cahill, H. E. Daly, D. Dineen, J. P. Deane, C. Heaps, M. Welsch, M. Howells, M. Bazilian, and B. P. Ó Gallachóir, "LEAPs and Bounds - an Energy Demand and Constraint Optimised Model of the Irish Energy System,” Energy Effic., vol. 7, no. 3, pp. 441-466, Jun. 2014.

[30] C. C. Koopmans, D. W. Te Velde, W. Groot, and J. H. A. Hendriks, "NEMO: Netherlands Energy demand MOdel A top-down model based on bottom-up information," p. 63, 1999.

[31] M. Jaccard and N. Rivers, "Combining Top-Down and Bottom-Up Approaches To Energy-Economy Modeling Using Discrete Choice Methods," Energy J., vol. 26, no. 1, pp. 83-106, 2005.

[32] B. Chateau and B. Lapillonne, "2.4. Accounting and end-use models," Energy, vol. 15, no. 3-4, pp. 261-278, Mar. 1990.

[33] I. A. Vera, L. M. Langlois, H. H. Rogner, A. I. Jalal, and F. L. Toth, "Indicators for sustainable energy development: An initiative by the International Atomic Energy Agency," Nat. Resour. Forum, vol. 29, no. 29, pp. 274-283, 2005.

[34] "Indicators of Sustainable Development: Guidelines and Methodologies," New York, USA, 2007.

[35] T. Fleiter, E. Worrell, and W. Eichhammer, "Barriers to energy efficiency in industrial bottom-up energy demand models-A review," Renew. Sustain. Energy Rev., vol. 15, no. 6, pp. 3099-3111, 2011.

[36] T. Suzuki, J. H. Williams, and P. Hayes, "Energy security and sustainability in Northeast Asia," Energy Policy, vol. 39, no. 11, pp. 6719-6730, 2011.

[37] H. Kim, E. Shin, and W. Chung, "Energy demand and supply, energy policies, and energy security in the Republic of Korea," Energy Policy, vol. 39, no. 11, pp. 6882-6897, 2011.

[38] M. A. H. Mondal, W. Boie, and M. Denich, "Future demand scenarios of Bangladesh power sector," Energy Policy, vol. 38, no. 11, pp. 7416-7426, 2010.

[39] R. Ghanadan and J. G. Koomey, "Using energy scenarios to explore alternative energy pathways in California," Energy Policy, vol. 33, no. 9, pp. 1117-1142, 2005.

[40] A. Phdungsilp, "Integrated energy and carbon modeling with a decision support system: Policy scenarios for lowcarbon city development in Bangkok," Energy Policy, vol. 38, no. 9, pp. 4808-4817, 2010.

[41] M. McPherson and B. Karney, "Long-term scenario alternatives and their implications: LEAP model application of Panama's electricity sector," Energy Policy, vol. 68, pp. 146-157, 2014.

[42] S. Bautista, "A sustainable scenario for Venezuelan power generation sector in 2050 and its costs," Energy Policy, vol. 44, pp. 331-340, 2012.

[43] L. Dagher and I. Ruble, "Modeling Lebanon's electricity sector: Alternative scenarios and their implications," Energy, vol. 36, no. 7, pp. 4315-4326, 2011.

[44] Q. Zhang, T. Weili, W. Yumei, and C. Yingxu, "External costs from electricity generation of China up to 2030 in energy and abatement scenarios," Energy Policy, vol. 35, no. 8, pp. 4295-4304, 2007.

[45] Y. Duval, "Environmental impact of modern biomass cogeneration in Southeast Asia," Biomass and Bioenergy, vol. 20, no. 4, pp. 287-295, 2001.

[46] S. Amous, D. Revet, and Y. Sokona, "Greenhouse gas abatement in Senegal A case study of least-cost options," Energy Policy, vol. 22, no. 11, pp. 947-954, Nov. 1994.

[47] I. Lozada, J. Islas, and G. Grande, "Environmental and economic feasibility of palm oil biodiesel in the Mexican transportation sector,” Renew. Sustain. Energy Rev., vol. 14, no. 1, pp. 486-492, 2010.

[48] Q. Zhang, W. Tian, Y. Zheng, and L. Zhang, "Fuel consumption from vehicles of China until 2030 in energy scenarios," Energy Policy, vol. 38, no. 11, pp. 6860-6867, 2010.

[49] H.-C. Shin, J.-W. Park, H.-S. Kim, and E.-S. Shin, "Environmental and economic assessment of landfill gas electricity generation in Korea using LEAP model," Energy Policy, vol. 33, no. 10, pp. 1261-1270, 2005.

[50] "Plan Estratégico de Ahorro y Eficiencia Energética," 2011.

[51] L. S. Sevillano R.C., Flores C.A., "Plan de Desarrollo Economico y Social: Efectos económicos hacia el 2030," 
La Paz, Bolivia, 2015.

[52] "Intended Nationally determined contribution from the Plurinational State of Bolivia," p. 17, 2015.

[53] “Memoria Institucional, Gestión 2012," 2013.

[54] "Elaboración de Proyectos de Guías de Orientación del Uso Eficiente de la Energía y de DIagnóstico Energético. Sector Comercial," 2008.

[55] "World Energy Investment Outlook 2014: Energy Efficiency Investment Asumptions,” p. 190, 2014.

[56] M. Howells, "The targeting of industrial energy audits for DSM planning," J. Energy South. Africa, vol. 17, no. 1, p. 8, 2006.

[57] A. Cezar-de-Lima, S. Camargo-Guimarães-Jr., C. R. Fietz, and J. R. Camacho, "Flujo energético e indicadores de eficiencia en pivotes centrales de riego," Agrociencia, vol. 42, no. 8, pp. 869-880, 2008.

[58] “Balance Energético Nacional 2000- 2013," 2014.

[59] "Anuario Estadístico 2013," 2014.

[60] "Estudios de base para el diseño de estrategias y políticas energéticas: relevamiento de consumos de energía sectoriales en términos de energía útil a nivel nacional," 2008.

[61] E. Ghisi, S. Gosch, and R. Lamberts, "Electricity end-uses in the residential sector of Brazil," Energy Policy, vol. 35, no. 8, pp. 4107-4120, 2007.

[62] P. Meier, V. Tuntivate, D. F. Barnes, S. V Bogach, and D. Farchy, "ESMAP, Peru: National Survey of Rural Household Energy Use," p. 190, 2010.

[63] W. Canedo, "Diagnóstico del sector energético en el area rural de Bolivia," p. 154, 2005.

[64] X. Wang, J. Franco, O. R. Masera, K. Troncoso, and M. X. Rivera, “¿Qué hemos aprendido del uso de biomasa para cocinar en los hogares de América Central?," p. 146, 2012.

[65] "Estadísticas del Parque Automotor 1998-2012," 2011.

[66] D. G. and M. S. Joyce Dargay, "Vehicle Ownership and Income Growth, Worldwide: 1960-2030 on JSTOR," Energy J., vol. 28, no. 4, pp. 143-170, 2007.

[67] "Sondeo sobre las operaciones de los principales operdores en el transporte urbano departamental," Instituto Nacional de Estadística. [Online]. Available: http://anda.ine.gob.bo/ANDA4_2/index.php/catalog/167/studydescription. [Accessed: 10-Oct-2015].

[68] "Encuesta del recorrido medio anual de los vehículos en circulación en Costa Rica," 2009.

[69] "EL Auto nuestro de cada día. El Parque Vehicular en Bolivia. Diagnóstico y Control,” 2011.

[70] IHS Global Inc., "EViews 7.” Irvine, USA.

[71] K. Whyte, H. E. Daly, and B. P. Ó Gallachóir, "Modelling HGV freight transport energy demand in Ireland and the impacts of the property construction bubble," Energy, vol. 50, pp. 245-251, 2013.

[72] "Estadísticas de la Actividad de Transporte 1990-2009," 2010.

[73] "Estimación del consumo de combustibles en el Transporte terrestre en Ecuador," 2015.

[74] "Memoria Anual," 2014.

[75] "Memoria Anual 2013," 2014.

[76] B. Vasigh, T. Tacker, and K. Fleeming, "Introduction to Air Transport Economics: From theory to Applications," p. $358,2008$.

[77] UNIDO, “Competitive Industrial Performance Report 2012/2013,” p. 170, 2013.

[78] INE, "Bolivia - Encuesta Anual a la Industria Manufacturera 2001,” 2003. [Online]. Available: http://catalog.ihsn.org/index.php/catalog/5954. [Accessed: 03-Mar-2015].

[79] G. G. MOLINA, "La economía boliviana;más allá del gas,” América Lat. Hoy, vol. 43, no. 0, 2009.

[80] "Handy manual in Cement Industry," p. 44, 1994.

[81] S. T. Anderson, “2012 Minerals Yearbook. BOLIVIA,” US Geol. Surv. Miner. Yearb., vol. 17, no. 28, pp. 19-20, 2009.

[82] F. Valdivia, "Incidencia de las reformas estructurales sobre la agricultura boliviana | Publication | Comisión Económica para América Latina y el Caribe," p. 52, 2000.

[83] "FAO," faostat3.fao.org, 2015. [Online]. Available: http://faostat3.fao.org/browse/I/RM/E. [Accessed: 05-Sep2015].

[84] "Encuesta Nacional Agropecuaria," 2009.

[85] R. . Eden, "Energy economics : growth, resources, and policies," p. 442, 1981.

[86] M. Jaccard, J. Nyboer, C. Bataille, and B. Sadownik, "Modeling the Cost of Climate Policy: Distinguishing Between Alternative Cost Deftitions and Long-Run Cost Dynamics,” Energy J., vol. 1, no. 24, pp. 49-73, 2003.

\section{Acknowledgements}

The authors gratefully acknowledge the support of Pamela Durán of Comité Nacional de Despacho de Carga (CNDC), Jorge Leiton of the Ministry of Energy in Bolivia for the collaboration of data supply and analysis, Mirna Mariscal, Marcelo Velazquez, Carlos Sevillano, Carla Flores Noya of Unidad de Análisis de Políticas Sociales y Económicas (UDAPE) and Eduardo Zepeda of the United Nations Division of Economic and Social 
Affairs (UNDESA) . Funding from the Swedish International Development Cooperation Agency (SIDA) and Vetenskapsrådet (VR) supported key elements of the research undertaken, and is thankfully received.

\section{Appendix}

Table A.1. Energy intensities used in the energy model

\begin{tabular}{|c|c|c|c|c|c|c|}
\hline Sector & Sub-sector & Technology & Fuel & Value 2012 & Value 2035 & Units \\
\hline \multirow{4}{*}{ Residential } & \multirow{2}{*}{ Urban-Electrified } & Appliances Normal fare & Electricity & 1937.800 & 2315.613 & kWh/hh-yy \\
\hline & & Appliances Reduced fare & Electricity & 581.800 & 575.610 & kWh/hh-yy \\
\hline & \multirow{2}{*}{ Rural- Electrified } & Appliances Normal fare & Electricity & 886.600 & 1208.271 & kWh/hh-yy \\
\hline & & Appliances Reduced fare & Electricity & 226.600 & 728.270 & kWh/hh-yy \\
\hline \multirow{29}{*}{ Transport } & \multirow{7}{*}{ Road-Private } & \multirow[t]{3}{*}{ Light duty } & Gasoline & 3.663 & 3.663 & $\mathrm{MJ} / \mathrm{km}$ \\
\hline & & & Diesel & 3.732 & 3.732 & $\mathrm{MJ} / \mathrm{km}$ \\
\hline & & & $\mathrm{CNG}$ & 3.700 & 3.700 & $\mathrm{MJ} / \mathrm{km}$ \\
\hline & & \multirow[t]{3}{*}{ Jeeps and Wagon } & Gasoline & 3.700 & 3.700 & $\mathrm{MJ} / \mathrm{km}$ \\
\hline & & & Diesel & 3.817 & 3.817 & $\mathrm{MJ} / \mathrm{km}$ \\
\hline & & & CNG & 3.868 & 3.868 & $\mathrm{MJ} / \mathrm{km}$ \\
\hline & & Motorcycles & Gasoline & 1.728 & 1.728 & $\mathrm{MJ} / \mathrm{km}$ \\
\hline & \multirow{12}{*}{ Road- Public } & \multirow[t]{3}{*}{ Taxi } & Gasoline & 0.953 & 0.953 & $\mathrm{MJ} / \mathrm{pkm}$ \\
\hline & & & Diesel & 0.688 & 0.688 & $\mathrm{MJ} / \mathrm{pkm}$ \\
\hline & & & $\mathrm{CNG}$ & 1.036 & 1.036 & $\mathrm{MJ} / \mathrm{pkm}$ \\
\hline & & \multirow[t]{3}{*}{ Minibus } & Gasoline & 0.614 & 0.614 & $\mathrm{MJ} / \mathrm{pkm}$ \\
\hline & & & Diesel & 0.570 & 0.570 & $\mathrm{MJ} / \mathrm{pkm}$ \\
\hline & & & CNG & 0.630 & 0.630 & $\mathrm{MJ} / \mathrm{pkm}$ \\
\hline & & \multirow[t]{3}{*}{ Microbus } & Gasoline & 0.358 & 0.358 & $\mathrm{MJ} / \mathrm{pkm}$ \\
\hline & & & Diesel & 0.249 & 0.249 & $\mathrm{MJ} / \mathrm{pkm}$ \\
\hline & & & CNG & 0.382 & 0.382 & $\mathrm{MJ} / \mathrm{pkm}$ \\
\hline & & \multirow[t]{3}{*}{ Omnibus } & Gasoline & 0.321 & 0.321 & $\mathrm{MJ} / \mathrm{pkm}$ \\
\hline & & & Diesel & 0.239 & 0.239 & $\mathrm{MJ} / \mathrm{pkm}$ \\
\hline & & & $\mathrm{CNG}$ & 0.318 & 0.318 & $\mathrm{MJ} / \mathrm{pkm}$ \\
\hline & \multirow[t]{3}{*}{ Freight- Urban } & \multirow[t]{3}{*}{ Pick-up trucks } & Gasoline & 5.683 & 5.683 & kboe/tkm \\
\hline & & & Diesel & 5.471 & 5.471 & kboe/tkm \\
\hline & & & CNG & 5.692 & 5.692 & kboe/tkm \\
\hline & \multirow{3}{*}{$\begin{array}{l}\text { Freight- } \\
\text { Interurban }\end{array}$} & \multirow[t]{2}{*}{ Truck } & Gasoline & 2.402 & 2.402 & kboe/tkm \\
\hline & & & Diesel & 1.552 & 1.552 & kboe/tkm \\
\hline & & Track-truck & Diesel & 0.504 & 0.504 & kboe/tkm \\
\hline & \multirow{2}{*}{ Rail } & Andean Rail & Diesel & 0.235 & 0.235 & $\mathrm{MJ} / \mathrm{tkm}$ \\
\hline & & Oriental Rail & Diesel & 0.292 & 0.292 & $\mathrm{MJ} / \mathrm{tkm}$ \\
\hline & \multirow{2}{*}{ Aviation } & Local flights & Jet fuel & 0.807 & 0.807 & kboe/pkm \\
\hline & & International flights & Jet Fuel & 0.609 & 0.609 & kboe/pkm \\
\hline \multirow{7}{*}{ Industry } & \multirow[t]{2}{*}{ Cement } & \multirow[t]{2}{*}{ All } & Electricity & 431.977 & 431.977 & MJ/tonne \\
\hline & & & $\begin{array}{l}\text { Natural } \\
\text { Gas } \\
\end{array}$ & 3252.407 & 3252.407 & MJ/tonne \\
\hline & \multirow[t]{5}{*}{ Manufacture } & Foods and beverages & All & 1.296 & 0.838 & $\begin{array}{l}\text { boe } / 10^{3} \mathrm{Bs} \\
(90 \text { 's })\end{array}$ \\
\hline & & Textile & All & 0.621 & 0,676 & $\begin{array}{l}\text { boe/ } 10^{3} \mathrm{Bs} \\
(90 \text { 's })\end{array}$ \\
\hline & & Metallic & All & 9.040 & 8.895 & $\begin{array}{l}\text { boe } / 10^{3} \mathrm{Bs} \\
\left(90^{\prime} \mathrm{s}\right)\end{array}$ \\
\hline & & Non metallic & All & 4.192 & 4.216 & $\begin{array}{l}\text { boe } / 10^{3} \mathrm{Bs} \\
(90 \text { 's) }\end{array}$ \\
\hline & & Other & All & 1.140 & 0.918 & $\begin{array}{l}\text { boe } / 10^{3} \mathrm{Bs} \\
(90 \text { 's) }\end{array}$ \\
\hline & All & All & Electricity & 0.255 & 0.328 & $\begin{array}{l}\text { boe/10 } 10^{3} \mathrm{Bs} \\
(90 \text { 's })\end{array}$ \\
\hline Commercial & & & $\begin{array}{l}\text { Gas and } \\
\text { LPG }\end{array}$ & 0.100 & 0.165 & $\begin{array}{l}\text { boe/10 } 10^{3} \mathrm{Bs} \\
(90 \text { 's })\end{array}$ \\
\hline & Mining & Zinc & Electricity & 1227.800 & 1080.464 & $\mathrm{kWh} /$ Tonne \\
\hline Minin ond Onounving & & & Diesel & 0.302 & 0.302 & boe/Tonne \\
\hline Mining and Quarrying & & Lead & Electricity & 1280.500 & 1126.840 & $\mathrm{kWh} /$ Tonne \\
\hline & & & Diesel & 1.430 & 1.430 & boe/Tonne \\
\hline
\end{tabular}




\begin{tabular}{lllllll} 
& & Tin & All & 1.497 & 1.411 & boe/Tonne \\
\cline { 2 - 6 } & Copper & All & 2.262 & 1.924 & boe/Tonne \\
\cline { 2 - 7 } & Quarrying & All & All & 0.569 & 0.554 & $\begin{array}{l}\text { boe/10 } \\
(90 \text { 's })\end{array}$ \\
\hline \multirow{3}{*}{ Agriculture } & All & Diesel & 0.498 & 0.498 & boe/hectare \\
\hline & Trucks & All & Diesel & 4.995 & 4.995 & boe/hectare \\
\cline { 3 - 7 } & & & Electricity & 2778.000 & 2778.000 & $\mathrm{kWh} /$ hectare \\
\hline
\end{tabular}

